\title{
Disintegrin and Metalloproteinase Domain-Containing Protein 17
}

National Cancer Institute

\section{Source}

National Cancer Institute. Disintegrin and Metalloproteinase Domain-Containing Protein

17. NCI Thesaurus. Code C48216.

Disintegrin and metalloproteinase domain-containing protein 17 (824aa, $\sim 93 \mathrm{kDa})$ is encoded by the human ADAM17 gene. This protein is involved in protein cleavage. 